\title{
Linkage analysis of the human insulin receptor gene in Type 2 (non-insulin-dependent) diabetic families and a family with maturity onset diabetes of the young
}

\author{
S. O'Rahilly ${ }^{1}$, R.C. Trembath ${ }^{3}$, P.Patel ${ }^{1}$, D.J.Galton ${ }^{3}$, R.C. Turner ${ }^{1}$ and J.S. Wainscoat ${ }^{2}$ \\ ${ }^{1}$ Diabetes Research Laboratories, Radcliffe Infirmary, ${ }^{2}$ Department of Haematology, John Radcliffe Hospital, Oxford, and \\ ${ }^{3}$ Medical Professorial Unit, St. Bartholomews Hospital, London, UK
}

\begin{abstract}
Summary. The possibility of linkage between the human insulin receptor gene locus and diabetes was examined in three Type 2 (non-insulin-dependent) diabetic families and one family with maturity onset diabetes of the young. Insulin receptor gene haplotypes were established using BgIII, Rsal and Sstl restriction enzyme digests of genomic DNA from all available family members. The digested DNA was subjected to agarose gel electrophoresis, Southern blotted, and hybridised to ${ }^{32}$ P-labelled human insulin receptor gene cDNA. In the pedigree with maturity onset diabetes of the young, formal linkage analysis allowed exclusion of close linkage between the insulin receptor locus and diabetes (logarithm of the odds for linkage versus non-linkage was -5.35 at recombination fraction of 0.01). This confirms the absence of linkage between insulin receptor and diabetes which has
\end{abstract}

been reported in two similar pedigrees. In the three Type 2 diabetic families there were a minimum of 4 recombinants between the insulin receptor locus and diabetes, which makes a direct role for insulin receptor defects unlikely. The importance of using realistic estimates of penetrance when performing linkage analysis in a disease with a late age of onset is emphasised. In contrast to the one previous linkage analysis study of the insulin receptor gene, no specific association of diabetes with the rare Sst1 S1(-) allele was observed in either the maturity onset diabetes of the young or the Type 2 diabetic families.

Key words: Genetics, Type 2 (non-insullin-dependent) diabetes, insulin receptor, linkage analysis, maturity onset diabetes of the young.
A major genetic component in Type 2 (non-insulin-dependent) diabetes has been repeatedly confirmed by both twin [1] and family studies [2]. Much of the available information suggests that the susceptibility to develop Type 2 diabetes is inherited as an autosomal dominant with penetrance being dependent on both age and obesity [3]. The early onset, mild familial diabetes referred to as maturity onset diabetes of the young (MODY) appears to have sufficient peculiarities of both age of onset and natural history to warrant consideration as a separate disorder [3]. In both these conditions, hyperglycaemia is a result of a combination of defects of both insulin secretion and action. Although some workers, including ourselves, have suggested that the primary defect is likely to reside in the $\mathrm{B}$ cell $[4,5]$, others have interpreted their data to suggest that resistance to the biological affects of insulin may occur at an earlier stage in the development of the disease with B-cell exhaustion being a secondary phenomenon $[6,7]$.

The cloning of the human insulin receptor gene [8] and the definition of polymorphisms around this locus [9] allows the investigation of the possible role of genetic defects in this locus in the causation of Type 2 diabetes. The most powerful technique for examining a genetic marker for its co-localisation with a disease is linkage analysis in large pedigrees. This has been strikingly successful recently in the chromosomal localisation of genetic defects in diseases in which the biochemical basis is unknown [10, 11]. In non-insulindependent diabetes this has been almost entirely restricted to MODY families which have a pedigree structure most amenable to this form of analysis [12]. There are considerable difficulties in applying this technique to Type 2 diabetes when the age of onset of the disease often means that parents of the proband are dead and the offspring have not yet developed the disease. We have ascertained several Type 2 diabetic families of a structure suitable for linkage analysis in whom the majority of subjects not known to have diabetes (including spouses) have been examined for glucose intolerance using a sensitive continuous infusion of glucose test [4]. In these families and in a MODY pedigree we have examined the inheritance of insulin receptor haplotypes and their possible linkage with diabetes. 
Table 1. Family BX. Clinical details of diabetic members of MODY pedigree BX. Note the early age of onset in the majority of family members and the predominance of diet as the treatment modality despite long duration of diabetes in some members. There is a notable absence of microvascular complications in this family. (Abbreviations: OHA - oral hypoglycaemic agents; IHD - ischaemic heart disease; PVD - peripheral vascular disease; IGT - impaired glucose tolerance)

\begin{tabular}{|c|c|c|c|c|c|c|c|c|c|c|c|}
\hline \multicolumn{2}{|c|}{ Subject } & \multirow{2}{*}{$\begin{array}{l}\text { Sex } \\
M\end{array}$} & \multirow{2}{*}{$\begin{array}{l}\text { Diabetic } \\
\text { status } \\
\text { D }\end{array}$} & \multirow{2}{*}{$\begin{array}{l}\text { Age at } \\
\text { diagnosis } \\
63\end{array}$} & \multirow{2}{*}{$\begin{array}{l}\begin{array}{l}\text { Duration of } \\
\text { diabetes (years) }\end{array} \\
15\end{array}$} & \multirow{2}{*}{$\begin{array}{l}\text { Body mass } \\
\text { index }\end{array}$} & \multirow{2}{*}{$\begin{array}{l}\text { Presenting } \\
\text { symptoms } \\
\text { Incidental }\end{array}$} & \multirow{2}{*}{$\begin{array}{l}\begin{array}{l}\text { Initial } \\
\text { therapy }\end{array} \\
\text { Diet }\end{array}$} & \multirow{2}{*}{$\begin{array}{l}\text { Time on initial } \\
\text { therapy (years) } \\
15\end{array}$} & \multirow{2}{*}{$\begin{array}{l}\text { Current } \\
\text { therapy } \\
\text { Diet }\end{array}$} & \multirow{2}{*}{$\begin{array}{l}\text { Compli- } \\
\text { cation }\end{array}$} \\
\hline III & 3 & & & & & & & & & & \\
\hline III & 9 & $\mathrm{~F}$ & $\mathrm{D}$ & 55 & 12 & 30.1 & Thirst & Diet & 12 & Diet & None \\
\hline III 1 & 10 & $\mathrm{~F}$ & D & 55 & 7 & 27.9 & Incidental & Diet & 7 & Diet & None \\
\hline III 1 & 15 & $\mathrm{M}$ & D & 14 & 54 & 20.6 & Incidental & Insulin & 19 & OHA & IHD, PVD \\
\hline IV & 8 & $\mathrm{~F}$ & D & 19 & 27 & 24.8 & In pregnancy & OHA & 27 & OHA & None \\
\hline IV 1 & 14 & $\mathbf{M}$ & D & 33 & 5 & 22.1 & Incidental & Diet & 5 & Diet & None \\
\hline IV 1 & 17 & $F$ & $\mathrm{D}$ & 21 & 4 & 22.1 & In pregnancy & Diet & 4 & Diet & None \\
\hline IV 1 & 19 & $\mathrm{M}$ & $\mathrm{D}$ & 11 & 2 & 22.6 & Incidental & Diet & 2 & Diet & None \\
\hline V & 5 & $\mathrm{~F}$ & $\mathrm{D}$ & 14 & 13 & 24.3 & Thirst & OHA & 13 & OHA & None \\
\hline
\end{tabular}

Table 2. Family AX. Clinical details of diabetic members of Type 2 diabetic families AX, BA and BF. See Table 1 for abbreviations

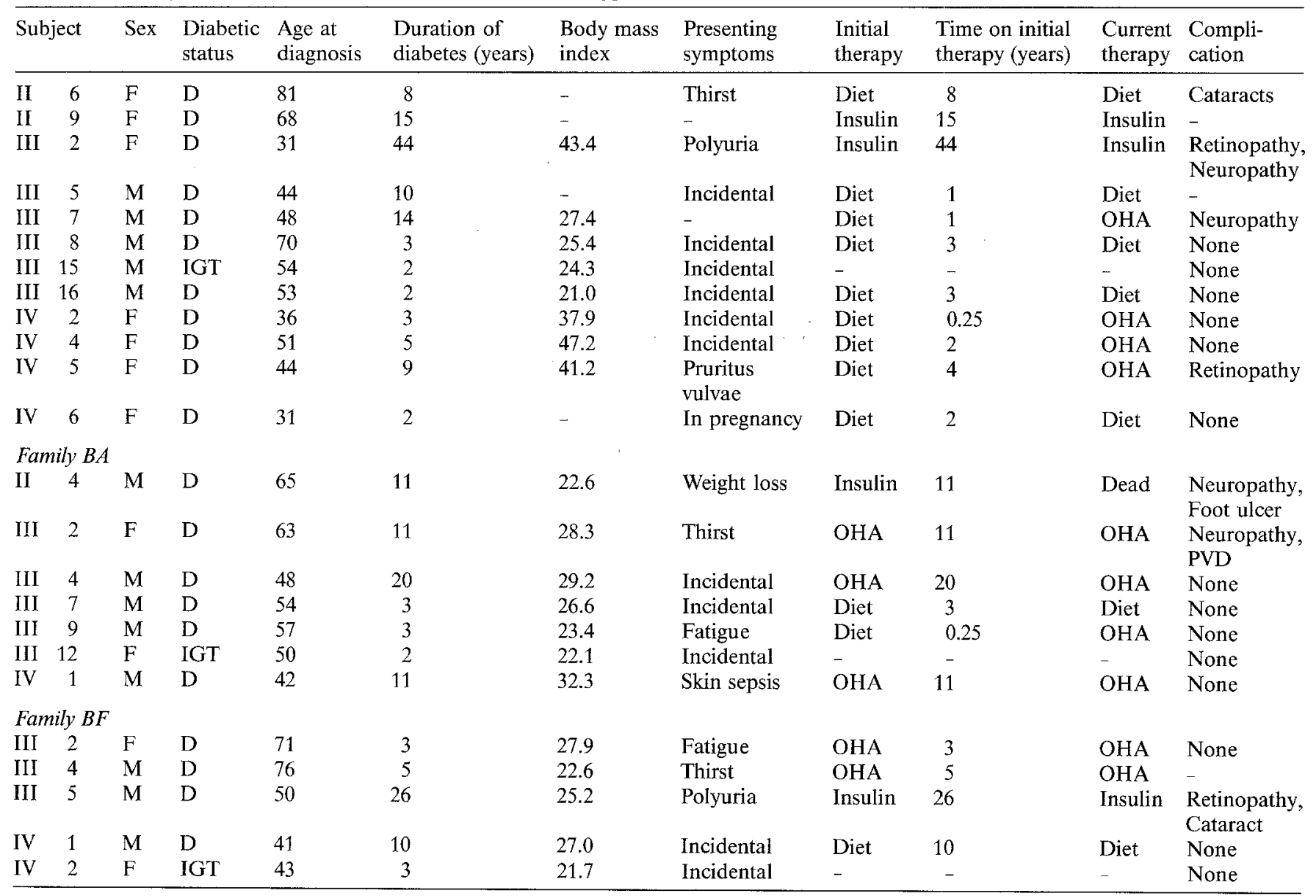

\section{Subjects and methods}

\section{Families}

All families were ascertained as part of a large family study conducted in the Oxford area. All participating members gave informed consent to the studies. Probands were ascertained through a diabetic clinic and all relatives known to have diabetes were contacted and asked to provide a blood sample. Their medical records were examined where possible. All other available family members were tested with either a fasting plasma glucose or a continuous infusion of glu- cose test. Families were examined for paternity using DNA fingerprinting techniques using probes p33.15 and p33.6 [13] (kindly supplied by Professor A.Jeffries) supplemented by the use of several single-locus hypervariable DNA probes (unpublished results).

Table 1 provides the clinical details on all the diabetic members of pedigree BX. This is a classical MODY pedigree with a history of diabetes over four generations, the age of onset being less than 25 years of age in a majority of family members. None of the family have required insulin for diabetes control, and none had microvascular complications.

Table 2 gives the clinical details of the diabetic members of families AX, BA and BF. In all cases the probands presented with 
non-insulin-dependent diabetes at more than 25 years of age. The clinical pattern of diabetes seen in these probands and their affected family members is indistinguishable from the usual Type 2 diabetes. As expected, several family members who were asymptomatic were found to have diabetes on testing.

\section{Definition of those subjects affected and unaffected}

The following subjects were considered affected:

1. Diagnosed diabetic by a physician and on oral hypoglycaemic agents, insulin treatment or a specific diet. The medical records of such subjects were examined where possible.

2. Fasting plasma glucose $>6 \mathrm{mmol} / \mathrm{l}$. This represents a value $>3$ standard deviations above the mean of a large normal population and has been used as the entry criterion for the UK Prospective Diabetes Study [14]

3. Plasma glucose $1 \mathrm{~h}$ after a continuous infusion of glucose $5 \mathrm{mg}$ glucose $\cdot \mathrm{kg}$ body weight ${ }^{-1} \cdot \mathrm{min}^{-1}>2$ standard deviations above

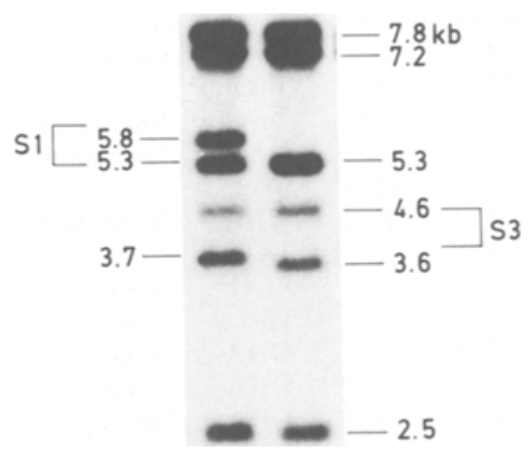

Fig. 1. Autoradiograph of Sst1 digested human genomic DNA hybridised to a ${ }^{32}$ P-labelled $1.3 \mathrm{~kb}$ Bgl1 fragment of the human insulin receptor cDNA showing the previously described S1 RFLP (5.8 and $5.3 \mathrm{~kb}$ ) and a new three allele RFLP (S3). When studied in 38 unrelated Caucasians the allelic frequencies were as follows: $4.6 \mathrm{~kb} 0.66$; $3.7 \mathrm{~kb} 0.04 ; 3.6 \mathrm{~kb} 0.30$ the mean of a matched control group [4]. In the families studied, only 2 subjects were classified as abnormal on the basis of an abnormal continuous infusion of glucose response and the majority of affected family members were clinically diabetic. Family members in whom either a fasting plasma glucose or response to a continuous infusion of glucose was not available were not included in the analysis.

\section{Restriction fragment length polymorphisms}

Five $\mu \mathrm{g}$ of genomic DNA was digested overnight with a 3-5-fold excess of the appropriate restriction enzymes under conditions specified by the manufacturer (Boehringer Research Labs, Paisley, UK). The sample was then electrophoresed in 1\% agarose gels and transferred using Southern blotting to nylon (Hybond-N, Amersham, U.K.). The filters were hybridised with fragments of the human insulin receptor (HIR) cDNA labelled with 32 deoxycytidine-triphosphate by hexanucleotide labelling using a commercial kit (Pharmacia, Milton Keynes, U.K.). A full length HIR complementary DNA (cDNA) probe HIR 12.1 (courtesy of Dr. A. Ullrich) was used to detect an Rsa1 polymorphism (R1) of $6.2(+)$ and $6.8(-) \mathrm{kb}$. A BglII polymorphism (B1) with allele sizes of either $20(+)$ or $23.4(-)$ was also detected using this probe. A $1.6 \mathrm{~kb}$ Pst1 fragment of the beta-chain cDNA (12.1 p 1.6) was used to detect an Sst1 polymorphism (S1) with allele sizes $5.3(+)$ and $5.8(-)$ kilobases. This nomenclature corresponds to that of Elbein et al. [9]. The $(-)$ allele of the Sst1 polymorphism actually represents a 500 base pair insertion [15].

Using this combination of probes and restriction enzymes we were unable to detect any additional polymorphisms, in particular the R2 and S2 polymorphisms described by Elbein et al. [9] with Rsa1 and Sst1 respectively, were not found. These polymorphisms are relatively uncommon in Caucasian populations. Using a $1.3 \mathrm{~kb}$ Bgl1 fragment $(12.1 \mathrm{~B} 1.3)$, which is a stretch of cDNA covering the junction of the alpha and beta chains, we identified a new high-frequency Sst1 RFLP which we refer to as S3 (Fig. 1) [16]. This is, however, in strong linkage disequilibrium with the R1 restriction fragment length polymorphism (RFLP) and provided no additional information in these families. Nonetheless this finding of a third Sst1 RFLP in the HIR locus could prove useful in large scale population studies where it is now possible to obtain a haplotype from a single Southern blot.

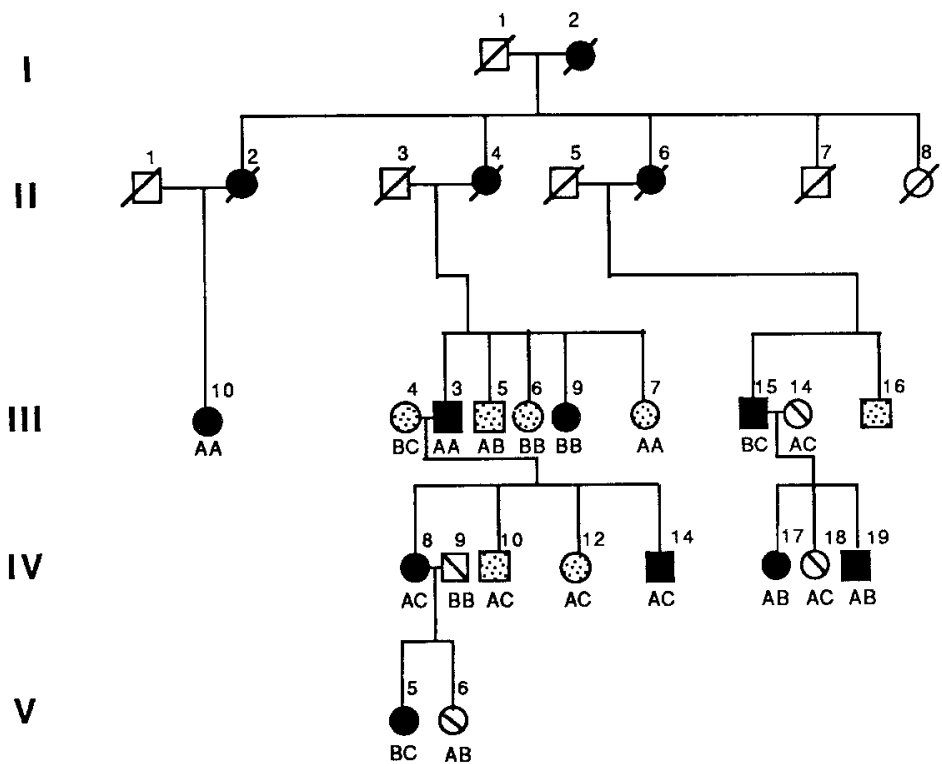

FAMILY BX
Fig. 2. Pedigree of the MODY family BX showing inheritance of insulin receptor haplotypes. Roman numerals on the left of the figure indicate generation number. Haplotypes are defined in the inset table. $\mathrm{R} 1=\mathrm{Rsa} 1, \mathrm{~B} 1=\mathrm{Bgl} \mathrm{II}, \mathrm{S} 1=\mathrm{SSt} 1$. For all RFLPs ' + ' implies the presence of a restriction site and ' - ' implies its absence. The same symbols are used in all family trees. There are several recombinants between the insulin receptor locus and diabetes in this family, e.g. affected siblings III 9 and III 3 do not have an allele in common. Subject V 5 has inherited allele C from her unaffected grandmother. The $\mathrm{S} 1(-)$ allele is unrelated to diabetes in this pedigree. Diabetic; $\mathbb{Q}$ Glucose intolerant; $\triangle$ Normal glucose tolerance; Normal fasting plasma glucose; $\square$ Dead; $\square$ Not tested 


\section{Statistical analysis}

Linkage analysis. Each family was considered separately for linkage. Each haplotype was assigned a letter as shown in Figure 2. Pedigrees were initially inspected for any recombinants between diabetes and the insulin receptor locus, and were subsequently subjected to formal LOD score analysis using the LINKAGE package [17] at recombination fractions varying from 0 (i.e. no recombinants, very tight linkage) to 0.5 (completely unlinked). The putative gene frequency used for Type 2 diabetes was 0.05 and for MODY was 0.001 . The data for Type 2 diabetes is based on prevalence studies in Caucasian populations [18]. No such data is available for MODY and the assumption of a gene frequency of one in a thousand probably represents an over-estimate. The use of a high figure will reduce the risk of obtaining a spurious LOD score, either positive or negative. The LINKAGE package allows the introduction of age-dependent penetrance factors which can considerably influence the statistical significance of the results. It mainly affects the weight given to the genetic information obtained from non-diabetic family members. This is based on the knowledge that diabetes prevalence increases

Table 3. Age of onset penetrances used in linkage analysis for the three putative genotypes (NN normal, ND heterozygote, DD homozygote) for both MODY and Type 2 diabetes. Penetrances are given for three liability classes based on age

\begin{tabular}{lllllllll}
\hline & & \multicolumn{3}{l}{ Penetrance } & & & \\
\cline { 3 - 8 } & & \multicolumn{2}{l}{ MODY } & \multicolumn{5}{l}{ Type 2 } \\
\hline $\begin{array}{l}\text { Liability } \\
\text { class }\end{array}$ & Age & NN & ND & DD & NN & ND & DD \\
1 & & & & & & & \\
2 & $>60$ & 0 & 1 & 1 & 0 & 0.8 & 0.95 \\
3 & $40-60$ & 0 & 0.9 & 1 & 0 & 0.6 & 0.9 \\
\hline
\end{tabular}

Table 4. LOD scores (logarithm of the odds for linkage versus non-linkage) for linkage between the insulin receptor locus and MODY in family $B X$

\begin{tabular}{ll}
\hline Recombination fraction & LOD score \\
\hline 0.001 & -9.00 \\
0.01 & -5.35 \\
0.05 & -2.67 \\
0.10 & -1.59 \\
0.20 & -0.64 \\
0.30 & -0.24 \\
0.40 & -0.06 \\
\hline
\end{tabular}

with age so that the confidence in a diagnosis of "non-diabetic" increases with the age of the subject and the stringency of the diagnostic test. Table 3 shows the penetrance factors used for (a) MODY and (b) Type 2 diabetes. For both diseases three liability classes were defined on the basis of age. The penetrance for MODY was estimated from the mean age of onset of the disease in both this pedigree and those reported by Tattersall [19]. For Type 2 diabetes, agerelated penetrance data was estimated from Köbberling et al. [20]. The values given in the Table refer to subjects who only had fasting plasma glucose measured. Subjects with a normal response to continuous infusion of glucose were placed in the liability class immediately above the one appropriate for their age.

\section{Results}

\section{MODY family $B X$}

Inspection of the family tree allows the identification of several recombinants between diabetes and the insulin receptor locus (Fig. 2). The failure of affected siblings III 3 and III 9 to share any insulin receptor alleles is firm evidence against tight linkage. Similarly, the affected Subject V 5 has inherited haplotype C from her affected mother who has in turn inherited this from her unaffected mother. The S1 $(-)$ allele is not related to diabetes in this family and is introduced via the unaffected spouses III 4 and III 14. Formal LOD score analysis effectively excludes the possibility that a defect in the insulin receptor gene is the cause of diabetes in this family (Table 4).

\section{Type 2 diabetic families}

In family AX (Fig. 3) subject III 2 transmits the "A" haplotype to all three affected daughters; however, she shares only haplotype " $D$ " with her affected sibling III 8. Their affected aunt II 9 transmits her "C" haplotype to one affected and one unaffected child. Only three of the haplotypes in generation I can be inferred; therefore, the relationship of the A haplotype in II-2 and II-9 cannot be determined. The S1(-)

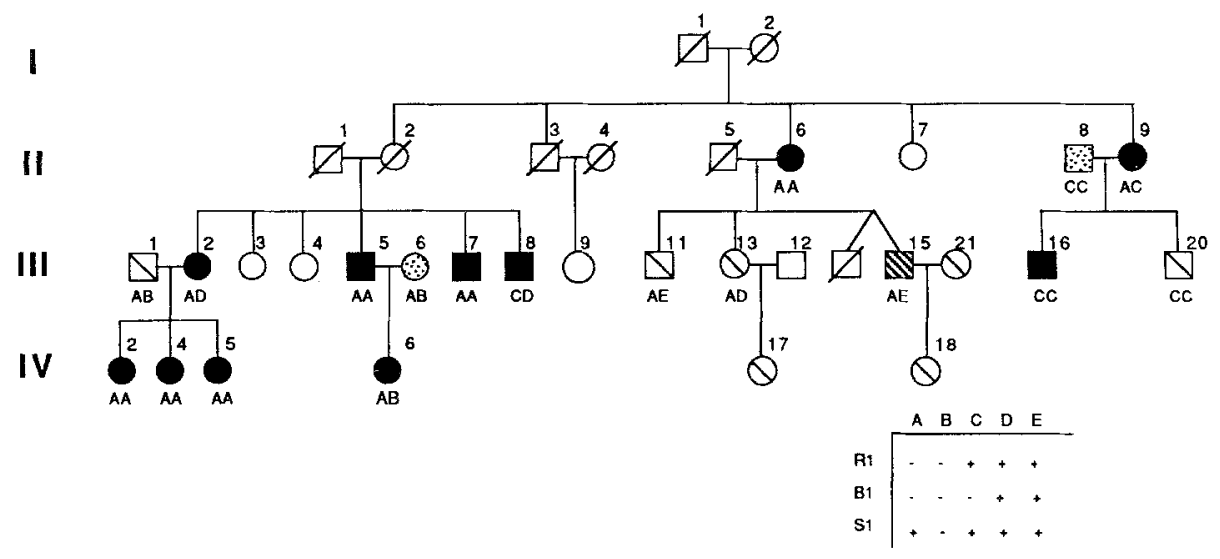

Fig. 3. Pedigree of Type 2 diabetic family $A X$ showing inheritance of insulin receptor haplotypes as defined in Figure 1. See Figure 2 for key to symbols. Subject III 2 transmits the A haplotype to her three affected daughters but shares only the D haplotype with her affected sibling III 8 . In addition subject 119 transmits haplotype $\mathrm{C}$ to both an affected and unaffected child. The $\mathrm{S} 1(-)$ allele is unrelated to diabetes in this pedigree 


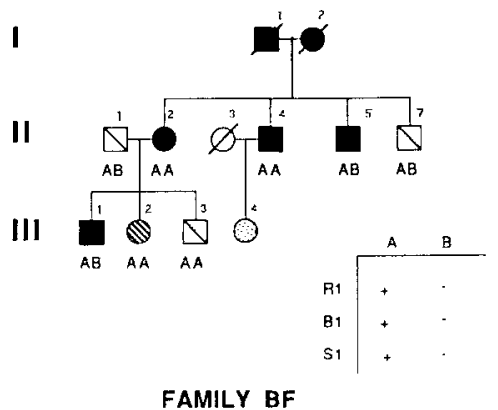

I

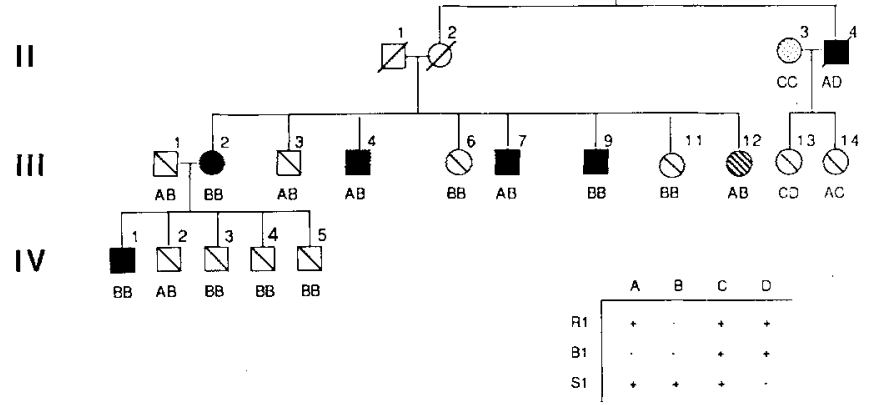

FAMILY BA

Fig. 4. Pedigrees of Type 2 diabetic families BA and BF. The insulin receptor locus is not highly informative in these families. Nonetheless, in family BA there is a crossover between subject II 4 and several of the affected siblings in generation III. In addition subject II 4 has transmitted different haplotypes to both his unaffected daughters. In neither of these pedigrees is diabetes related to the S1(-) allele. Symbols as in Fig.2

polymorphism is present only in the affected subjects IV 6 who has inherited this from her unaffected mother. If Type 2 diabetes were a rare genetic disease, then close linkage to the insulin receptor locus would be effectively excluded in this family. However, the use of a $5 \%$ gene frequency for Type 2 diabetes in formal LOD score analysis introduces the finite possibility that both subjects II 1 and II 2 had diabetes. In addition the use of an age-dependent penetrance factor admits the possibility that subject III 20 has inherited a "diabetic gene" but has not yet expressed the phenotype. Therefore the LOD score at recombination fraction of 0.01 does not reach formal statistical significance.

In family BA (Fig. 4) the affected subject II 4 does not share the " $B$ " haplotype found in many diabetic and non-diabetic pedigree members. In addition, he transmits different alleles to both his unaffected daughters. In this family, II 4 is the only member to have the S1 (-) allele. Family BF (Fig.4) is not very informative as subject II 2 is homozygous for insulin receptor haplotypes, and is additionally complicated by having two affected parents in generation I. As in the other families there is no selective transmission of the $\mathrm{S} 1(-)$ allele to the diabetic members.

\section{Discussion}

Linkage analysis is a powerful tool for examining the role of candidate genes in the aetiology of inherited diseases with a defined mode of transmission [21]. Families with MODY are particularly amenable to this form of investigation as they have clearly discernable autosomal dominant inheritance, the early age of onset allows ascertainment of affected members over three generations, and the relatively benign course means that family members in older generations are often alive and available for investigation [19]. Several studies have used linkage analysis in MODY pedigrees to investigate serum protein and red-cell enzyme polymorphisms [22], HLA antigens [23], the insulin gene [24-26], and the insulin receptor gene [15]. No study to date has found significant linkage. Elbein et al. recently reported results of linkage analysis of the human insulin receptor (HIR) gene in four diabetic pedigrees [15], two of which strictly conform to the definition of MODY suggested by Tattersall [27]. In these two pedigrees there were several recombinants between the HIR locus and diabetes and although individual LOD scores were not provided the data clearly disproved the hypothesis of linkage in these families. In our family BX we also exclude linkage to the HIR locus with a LOD score of -5.35 at a recombination fraction of 0.01 . In addition we can formally exclude linkage to a region around the HIR gene on chromosome 19 of more than 5 centiMorgans.

Type 2 diabetes has rarely been studied using linkage analysis because the mode of inheritance has been unclear and there have been few pedigrees with a structure suitable for such analysis. The difficulty in defining the mode of inheritance of Type 2 diabetes has been largely due to the late onset of the disease and the frequency of undiagnosed diabetes. Family studies such as those of Köbberling [18] which apply accepted techniques of statistical extrapolation to estimate ultimate prevalence, or those performed by ourselves [28] which test unaffected members with sensitive tests of glucose tolerance, suggest that the susceptibility to Type 2 diabetes may be inherited as an autosomal dominant. The three Type 2 diabetic pedigrees described in this paper are of a form suitable for linkage analysis although potential problems arise from having two affected parents, as in family BF.

In both family BA and $\mathrm{AX}$ there are recombinants between the HIR locus and diabetes which would appear to exclude tight linkage. When performing linkage analysis in Type 2 diabetes, the complicating factors of high disease prevalence and late age of onset have to be taken into account. Until the genetics of diabetes are more clearly defined the precise figures used for these variables are arbitrary. It is unrealistic to assume $100 \%$ penetrance irrespective of age and figures derived from the age of onset in the families under investigation would appear to be a reasonable 
compromise. This will reduce the chance of spuriously elevated LOD scores whether positive or negative. Unlike Elbein and colleagues [15] our data did not suggest a relationship between the rare $S 1(-)$ allele and diabetes in any of the families.

In conclusion, inherited abnormalities or variations in and around the insulin receptor gene are unlikely to be directly responsible for the majority of Caucasian families with Type 2 diabetes or MODY. This would be in accord with the physiological data obtained on these and other British Caucasian families which suggest that the B cell may be the site of the first detectable physiological abnormality [4, 28, 29]. Nevertheless, it is possible that genetic variation at the HIR locus may play a role in the determination of insulin resistance and thus influence the development of diabetes in subjects who are otherwise genetically predisposed. In addition it is possible that families exist in whom inherited insulin receptor defects determine the development of diabetes. Presumably in these families insulin resistance will be an early and pre-eminent feature. The role of insulin receptor defects in diabetes in non-Caucasian families remains to be explored.

Acknowledgements. We thank the Medical Research Council for support, Dr. R.Spivey for her assistance with family studies, Drs. A. King and $\mathrm{S}$. Reeders for assistance with linkage analysis and Ms. P. Farmer for the preparation of the manuscript. SOR was the British Diabetic Association Redcliffe Maude fellow during these studies and is the recipient of a Travelling studentship of the National University of Ireland.

\section{References}

1. Barnett AH, Eff C, Leslie RDG, Pyke DA (1981) Diabetes in identical twins: a study of 200 pairs. Diabetologia 20: 87-93

2. Steinberg AG (1961) Heredity in Diabetes mellitus. Diabetes 10: 269-274

3. O'Rahilly S, Turner RC (1988) Early onset Type II diabetes $\mathrm{V}$ MODY: evidence for the existence of two discrete diabetic syndromes. Diabetic Medicine 5: 224-229

4. O'Rahilly SP, Nugent Z, Rudenski AS, Hosker JP, Burnett MA, Darling P, Turner RC (1986) Beta-cell dysfunction, rather than insulin insensitivity is the primary defect in familial type 2 diabetes. Lancet I: $360-363$

5. Cerasi E, Luft R, Efendic S (1972) Decreased sensitivity of the pancreatic beta cells to glucose in prediabetic and diabetic subjects. Diabetes 21: 224-234

6. Reaven GM (1984) Insulin secretion and insulin action in noninsulin-dependent diabetes mellitus: Which defect is primary? Diabetes Care 7: 17-24

7. Olefsky JM, Ciaraldi TP, Kolterman OG (1985) Mechanisms of insulin resistance in non-insulin-dependent (Type II) diabetes. Am J Med 79: 12-22

8. Ulirich A, Bell JR, Chen EY, Herrara R, Petruzzelli LM, Dull TJ, Gray A, Coussens L, Liao YC, Tsubokawa M, Mason A, Seeburg PH, Grunfeld C, Rosen OM, Ramachandran J (1985) Human insulin receptor and its relationship to the tyrosine kinase family of oncogenes. Nature 313: 756-761

9. Elbein SC, Corsetti L, Ulirich A, Permutt MA (1986) Multiple restrictions fragment length polymorphisms at the insulin receptor locus: a highly informative marker for linkage analysis. Proc Natl Acad Sci 83: 5223-5227

10. Knowlton RG, Cohen-Haguenauer O, Van Cong N, Frezal J, Brown VA, Barker D, Braman JC, Schumm JW, Tsui LC, Buch- wald M, Donis-Keller H (1985) A polymorphic DNA marker linked to cystic fibrosis is located on chromosome 7. Nature 318: 381-382

11. Reeders ST, Breuning MH, Davies KE, Nicholls RD, Jarman AP, Weatherall DJ (1985) A highly polymorphic DNA marker linked to adult polycystic kidney disease on chromosome 16 . Nature 317: 542-544

12. Deschamps I, Lestradet H, Demenais F, Feingold N, Schmid M, Hors J (1983) A linkage study of HLA and maturity-onset type diabetes of the young (MODY). Tissue Antigens 21: 391-396

13. Jeffreys AJ, Wilson V, Thein SL (1985) Hypervariable 'minisatellite' regions in human DNA. Nature 314: 67-73

14. Multicentre Study (1983) UK Prospective study of therapies of Maturity-Onset Diabetes. Diabetologia 24: 404-411

15. Elbein SC, Borecki I, Corsetti L, Fajans SS, Hansen AT, Nerup J, Province M, Permutt MA (1987) Linkage analysis of the human insulin receptor gene and maturity onset diabetes of the young. Diabetologia 30: 641-647

16. Patel P, O'Rahilly S, Ullrich A, Turner RC, Wainscoat JS (1988) A new Sst1 RFLP associated with the insulin receptor locus. Nucleic Acids Res 16: 5700

17. Lathrop GM, Ireland JM (1984) Easy Calculation of LOD Scope and Genetic Risks on Small Computers. Am J Hum Genet 36: 460-465

18. Zimmet P (1982) Type 2 (non-insulin-dependent) diabetes - an epidemiological overview. Diabetologia 22: 399-411

19. Tattersall RB, Fajans S (1975) A difference between the inheritance of classical juvenile-onset and maturity-onset type diabetes of young people. Diabetes $24: 44-53$

20. Köbberling J, Tillil H (1982) Empirical risk figures for first degree relatives of non-insulin dependent diabetics. In: Köbberling J J Tattersall $\mathbf{R}$ (eds) The genetics of Diabetes Mellitus. Academic Press, London, pp 201-209

21. Ott J (1985) Analysis of human genetic linkage, 1st edn. John Hopkins University Press, Baltimore

22. Serjeantson SW, Zimmet $P$ (1982) Analysis of linkage relationships in maturity-onset diabetes of young people and independent segregation of $\mathrm{C} 6$ and HLA. Hum Genet 62: 214-216

23. Barbosa J, King R, Goetz FC, Uns EJ (1978) HLA in maturityonset type of hyperglycaemia in the young. Arch Intern Med 138: $90-93$

24. Bell JI, Wainscoat JS, Old JM, Chlouverakis C, Keen H, Turner RC, Weatherall DJ (1983) Maturity-Onset Diabetes of the Young is not linked to the Insulin Gene. Br Med J 286: 590-592

25. Andreone T, Fajans S, Rotwein P, Skolnick M, Permutt A (1985) Insulin gene analysis in a family with maturity onset diabetes of the young. Diabetes $34: 108-112$

26. Hitman GA, Jowett NI, Williams LG, Humphries S, Winter RM, Galton DJ (1984) Polymorphisms in the 5'-flanking region of the insulin gene and non-insulin-dependent diabetes. Clin Sci 66: 383-388

27. Tattersall RB (1974) Mild familial diabetes with dominant inheritance. Q J Med 43: 339-357

28. O'Rahilly S, Spivey RS, Holman RR, Nugent Z, Clark A, Turner RC (1987) Type II diabetes of early onset: a distinct clinical and genetic syndrome? Br Med J 294: 923-928

29. O'Rahilly S, Turner RC, Matthews DR (1988) Impaired pulsatile secretion of insulin in relatives of patients with non-insulin dependent diabetes. N Engl J Med 318: 1225-1230

Received: 30 May 1988

and in revised form: 6 September 1988

Dr. S.O'Rahilly

Diabetes Research Laboratories

Nuffield Department of Clinical Medicine

Radcliffe Infirmary

Woodstock Road

Oxford OX2 6HE

UK 